\title{
ANALYSIS OF COMPOSITE BEAM USING ANSYS
}

\author{
Jayalin.D ${ }^{1}$, Prince Arulraj. G ${ }^{2}$, Karthika. $V^{3}$ \\ ${ }^{1}$ Assistant Professor, SNS College of Technology, Coimbatore-641035, India \\ jayalinsnsct@gmail.com \\ ${ }^{2}$ Dean, Dept. of civil engineering, SNS College of Technology, Coimbatore-641035, India \\ deancivil@snsct.org \\ ${ }^{3}$ PG Scholar, SNS College of Technology, Coimbatore - 641035, India \\ vkarthikaa@gmail.com
}

\begin{abstract}
A Finite Element (FEM) model has been developed using Ansys 15 to analyse beams with openings. The openings in beams are provided for utility ducts and pipes. The cracks normally develop due to the stress concentration around the openings. In this paper, beams strengthened by Carbon Fibre Reinforced Polymer (CFRP) and Glass Fibre Reinforced Polymer (GFRP) Concrete sheets were studied. The concrete was modelled using solid 65 element and rebars were modelled using beam 188 elements. Thirteen beams were modelled, one beam is the reference reinforced concrete beam without any opening. Six beams with openings retrofitted with CFRP fibres and six beams with opening retrofitted with GFRP were also analysed. From the analysis, the load deflection relationship, crack pattern and crack at ultimate load were obtained and comparison was done for CFRP and GFRP beams. From the load deflection relationship, it was found that the performance of beams retrofitted with CFRP was better than that of the beams retrofitted with GFRP. The strengthening with CFRP and GFRP around and inside the opening was found more effective in improving the ultimate load carrying capacity of beams.
\end{abstract}

Keywords: Reinforced concrete beam, CFRP, GFRP, Load carrying capacity

\section{INTRODUCTION}

Composite materials are made from two or more constituent materials with different physical and chemical properties that when combined produce a material with characteristics different from the individual components. Most commonly used composite material is Fibre reinforced plastic. Fibre reinforced plastic is a composite material made of a polymer matrix reinforced with fibres. Generally, the utility ducts were provided for pipes electric cables, etc., The presence of the opening leads to reduction in stiffness, cracking, excessive deflection and reduction in the strength of the beam. A rectangular opening may be considered as a small opening when the depth or diameter is $\leq 0.4$ times of overall beam depth. The common methods for strengthening are wrapping of Carbon Fiber Reinforced Polymer Sheets, Aramid Fiber Reinforced Polymer Sheets (AFRP), Glass Fiber Reinforced Polymer Sheets, strengthening by Steel Plates and Strengthening by steel reinforcement.

In this paper, different types of strengthening techniques using CFRP and GFRP Sheets were carried out. One Reinforced Concrete beam was the reference specimen. Six beams had opening retrofitted with CFRP fibres and six other beams were retrofitted with GFRP sheets. Three out of six beams had openings in the shear zone and the other three had openings in the flexure zone. The CFRP and GFRP sheets were wrapped inside the opening, around the opening, both inside and around the opening. The results obtained for the CFRP wrapped beams were compared with the results obtained for GFRP wrapped beams and also compared with the Reinforced Concrete beam results.

\section{LITERATURE REVIEW:}

Shaishav $\mathbf{R}$ et. al (2014) discussed about the comparative study of experimental and analytical results of FRP strengthened beams in flexure. Two beams were modelled using ANSYS finite element program and in those two beams, one beam was without FRP and other beam was Glass Fibre Reinforced Polymer (GFRP) strengthened beams. The load deflection relationships, crack pattern, ultimate load was obtained and compared with the experimental results available in literature and obtained results shows good agreement with the experimental results.

Santhakumar $\mathbf{R}$ and Chandrasekaran (2004) made the analysis of retrofitted reinforced concretes shear beams using carbon fibre composites. In this paper, a study on the unretrofitted RC beam designated as control beam, RC beams retrofitted with CFRP composites in uncracked and precracked beams were studied. The modeling was done in ANSYS and quarter of the beam modelled on the bases of symmetry. The results obtained was in good agreement with the experimental plots.

Lavate1 R. S et. al (2010) presented about dynamic response analysis of fibre reinforced composite beam. The dynamic analysis of the composite beam was studied and values of Young Modulus, Poisson's ratio and shear modulus were determined. The longitudinal and transverse 
vibrations were determined numerically and experimentally. These outputs were transferred to the graphs.

Omran H.Y et. al (2009) explained about finite element modelling of steel-concrete composite beams strengthened with prestressed CFRP plate. Beams strengthened with Carbon Fibre Reinforced Polymer and the beams were modelled using ANSYS. The obtained results was compared with the experimental one and was found to be in good agreement.

\section{PROPOSED METHOD OF ANALYSIS:}

For the current research, a beam of length $1800 \mathrm{~mm}$, width $150 \mathrm{~mm}$ and depth $250 \mathrm{~mm}$ is considered. The top longitudinal reinforcement consists of four bars of $12 \mathrm{~mm}$ diameter and the bottom longitudinal reinforcement consists of two bars of $8 \mathrm{~mm}$ diameter with spacing $150 \mathrm{~mm}$. The size of the opening was $200 \times 100 \mathrm{~mm}$ was provided.

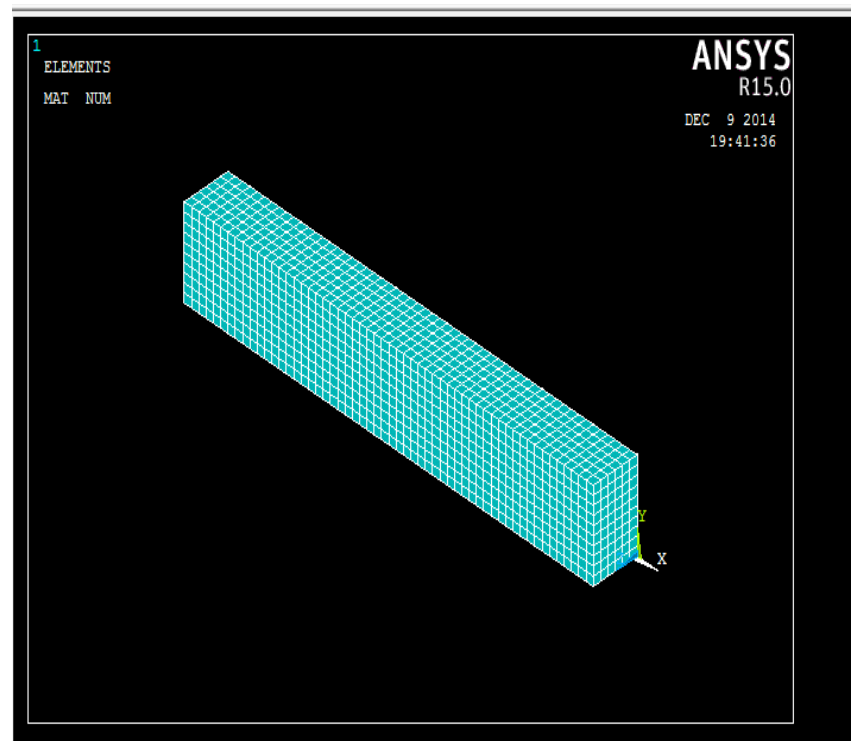

Figure1. Modelling of RC beam

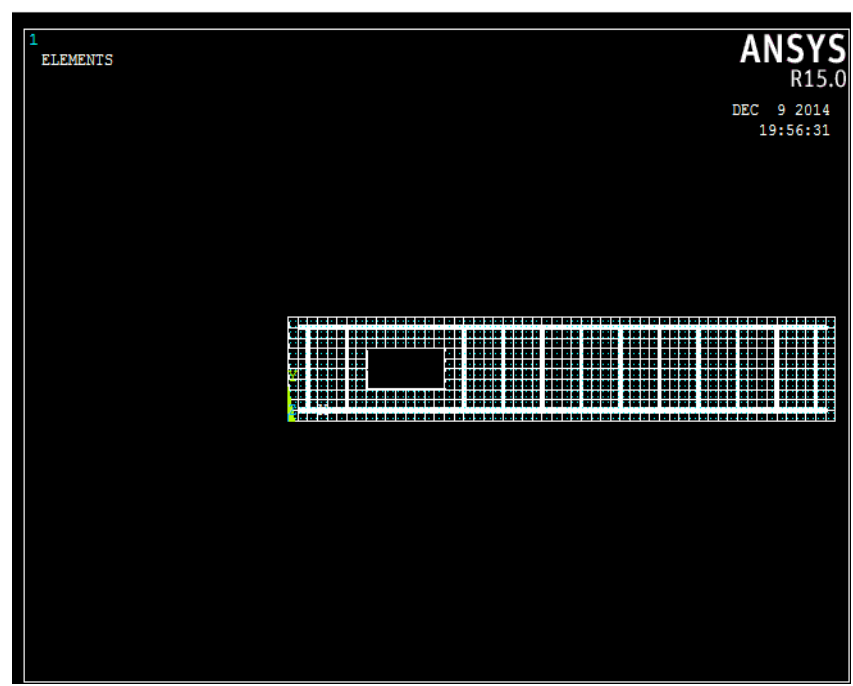

Figure 2. Modelling of beam with opening in shear zone

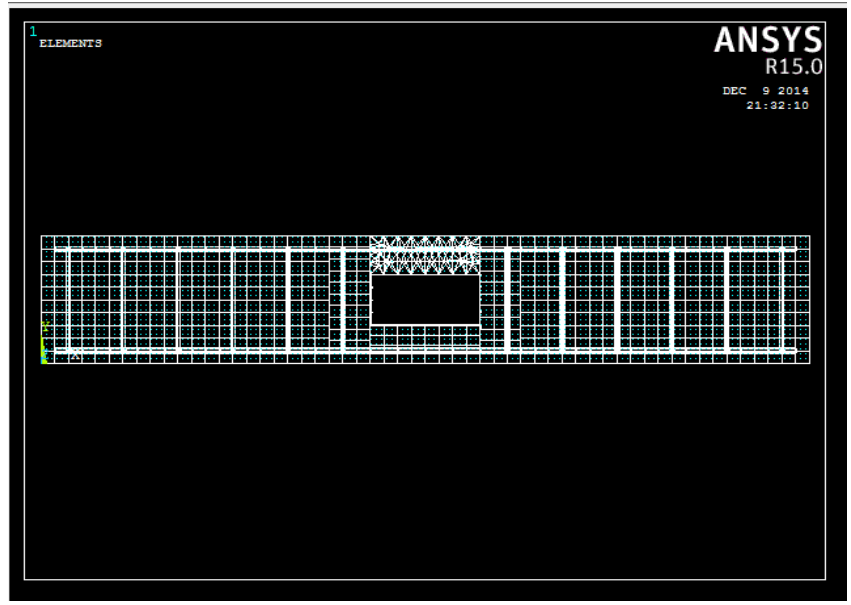

Figure 3. Modelling of beam with opening in flexural zone.

In ANSYS 15, the Elements used for analysis of beams were Solid 65, Beam 188 and Solid 185. Solid 65 was used for the three- dimensional modeling of concrete. The elements is defined by 8 nodes. Solid 186 was used for solid structures. Beam 188 was a linear beam element and is used for steel reinforcement. This element is based on Timoshenko beam theory. In this element, shear deformation effects are included. The elements are given in Table 1.

Table 1. Elements used

\begin{tabular}{|c|c|c|}
\hline Material type & Elements & No. od nodes \\
\hline Concrete & Solid 65 & 8 \\
\hline Steel & Beam 188 & 2 \\
\hline CFRP and GFRP & Solid 185 & 8 \\
\hline
\end{tabular}

The material properties of concrete given as input for it ANSYS model are given in Table 2.

Table 2. Material Properties of Concrete for the Proposed Model

\begin{tabular}{|l|c|}
\hline $\begin{array}{l}\text { Young's modulus of concrete } \\
\mathrm{kN} / \mathrm{m}^{2}\end{array}$ & $2.23 * 10^{4}$ \\
\hline Poisson's ratio of concrete & 0.15 \\
\hline Open shear transfer coefficient & 0.23 \\
\hline Closed shear transfer coefficient & 0.9 \\
\hline Uniaxial cracking stress & 2.5 \\
\hline Uniaxial crushing stress & -1 \\
\hline
\end{tabular}

The shear transfer coefficient shows the Crack face and the value ranges from 0.0 to 1.0 . The value 0.0 represent the smooth crack and 1.0 represent the rough crack

The material properties of steel given as input for it ANSYS model are given in Table 3.

Table 3. Material Properties of Steel for the Proposed Model

\begin{tabular}{|l|l|}
\hline Young's modulus of concrete $\mathrm{kN} / \mathrm{m}^{2}$ & $2 * 10^{5}$ \\
\hline Poisson's ratio of concrete & 0.3 \\
\hline Yield stress of steel & 415 \\
\hline
\end{tabular}

The material properties of CFRP given as input for the ANSYS model are given in Table4. 
Table 4. Material Properties of CFRP

\begin{tabular}{|l|l|l|}
\hline $\begin{array}{l}\text { Elastic modulus of elasticity } \\
\text { in } \mathrm{x} \text { direction } \mathrm{kN} / \mathrm{m}\end{array}$ & $\mathrm{Ex}$ & $2.3 * 10^{5}$ \\
\hline $\begin{array}{l}\text { Elastic modulus of elasticity } \\
\text { in y direction } \mathrm{kN} / \mathrm{m}\end{array}$ & $\mathrm{Ey}$ & $1.79 * 10^{4}$ \\
\hline $\begin{array}{l}\text { Elastic modulus of elasticity } \\
\text { in z direction } \mathrm{kN} / \mathrm{m}\end{array}$ & $\mathrm{Ez}$ & $1.79^{*} 10^{4}$ \\
\hline Poisson's ratio in $\mathrm{x}$ direction & PRXY & 0.22 \\
\hline Poisson's ratio in y direction & PRYZ & 0.3 \\
\hline Poisson's ratio in z direction & PRXZ & 0.22 \\
\hline $\begin{array}{l}\text { Shear modulus in } \mathrm{x} \text { direction } \\
\mathrm{kN} / \mathrm{m}^{2}\end{array}$ & Gxy & 11790 \\
\hline $\begin{array}{l}\text { Shear modulus in y direction } \\
\mathrm{kN} / \mathrm{m}^{2}\end{array}$ & Gyz & 6880 \\
\hline $\begin{array}{l}\text { Shear modulus in } \mathrm{z} \text { direction } \\
\mathrm{kN} / \mathrm{m}^{2}\end{array}$ & Gxz & 11790 \\
\hline
\end{tabular}

The material properties of GFRP given as input for the ANSYS model are given in Table 5

Table 5. Material Properties of GFRP

\begin{tabular}{|l|l|l|}
\hline $\begin{array}{l}\text { Elastic modulus of elasticity } \\
\text { in } \mathrm{x} \text { direction } \mathrm{kN} / \mathrm{m}\end{array}$ & $\mathrm{Ex}$ & $2.1^{*} 10^{5}$ \\
\hline $\begin{array}{l}\text { Elastic modulus of elasticity } \\
\text { in y direction } \mathrm{kN} / \mathrm{m}\end{array}$ & $\mathrm{Ey}$ & $7 * 10^{3}$ \\
\hline $\begin{array}{l}\text { Elastic modulus of elasticity } \\
\text { in z direction } \mathrm{kN} / \mathrm{m}\end{array}$ & $\mathrm{Ez}$ & $7 * 10^{3}$ \\
\hline Poisson's ratio in x direction & PRXY & 0.26 \\
\hline Poisson's ratio in y direction & PRYZ & 0.26 \\
\hline Poisson's ratio in z direction & PRXZ & 0.30 \\
\hline $\begin{array}{l}\text { Shear modulus in x direction } \\
\mathrm{kN} / \mathrm{m}^{2}\end{array}$ & Gxy & 1520 \\
\hline $\begin{array}{l}\text { Shear modulus in y direction } \\
\mathrm{kN} / \mathrm{m}^{2}\end{array}$ & Gyz & 1520 \\
\hline $\begin{array}{l}\text { Shear modulus in z direction } \\
\mathrm{kN} / \mathrm{m}^{2}\end{array}$ & Gxz & 2650 \\
\hline
\end{tabular}

\section{RESULTS AND DISCUSSIONS}

\subsection{RESULTS}

Table 6 shows the Comparison of maximum deflection of various types of beams.

Table 6. Comparison of maximum deflection

\begin{tabular}{|l|c|c|}
\hline \multicolumn{1}{|c|}{ Beam } & $\begin{array}{l}\text { Deflection for CFRP } \\
(\mathrm{mm})\end{array}$ & $\begin{array}{l}\text { Deflection for } \\
\text { GFRP }(\mathrm{mm})\end{array}$ \\
\hline RC beam & 7.00258 & 7.0028 \\
\hline $\begin{array}{l}\text { CFRP inside the opening } \\
\text { in shear zone }\end{array}$ & 8.673 & 8.2792 \\
\hline $\begin{array}{l}\text { CFRP around the opening } \\
\text { in shear zone }\end{array}$ & 5.848 & 6.49041 \\
\hline $\begin{array}{l}\text { CFRP inside and around } \\
\text { the opening in shear zone }\end{array}$ & 5.684 & 6.1728 \\
\hline $\begin{array}{l}\text { CFRP inside the opening } \\
\text { in Flexural zone }\end{array}$ & 3.2351 & 2.0221 \\
\hline $\begin{array}{l}\text { CFRP around the opening } \\
\text { in Flexural zone }\end{array}$ & 3.17 & 2.01426 \\
\hline $\begin{array}{l}\text { CFRP inside and around } \\
\text { the opening in Flexural } \\
\text { zone }\end{array}$ & 1.934 & 2.00221 \\
\hline
\end{tabular}

\subsection{DISCUSSIONS}

From the results, the presence of opening in shear zone and flexural zone not only reduces the load carrying capacity but also reduces the stiffness of the beam. The load carrying capacity was increased by strengthing the beams with CFRP and GFRP. The load carrying capacity of both inside and around the opening of the beam was maximum when compared to inside the opening, around the opening for CFRP and GFRP. In the case of both inside and around the opening, the load carrying capacity for CFRP was maximum compared to GFRP techniques due to deflection is minimum in that.

The load deflection graph for the beams retrofitted with CFRP in shear zone is shown in Figure 4.

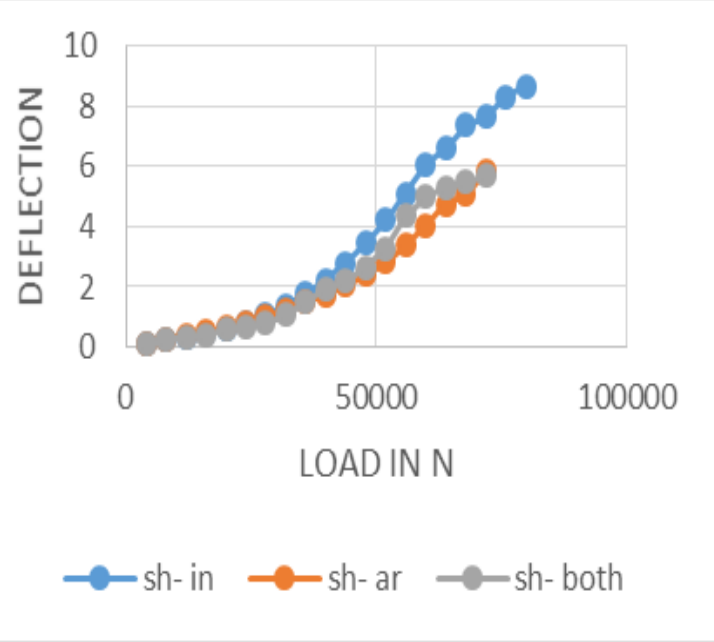

From the figure, it can be seen that the deflection are minimum for a given load in case of beams retrofitted with CFRP inside and around the opening in Shear zone.

The load deflection graph for the beams retrofitted with CFRP in Flexural zone is shown in Figure 5.

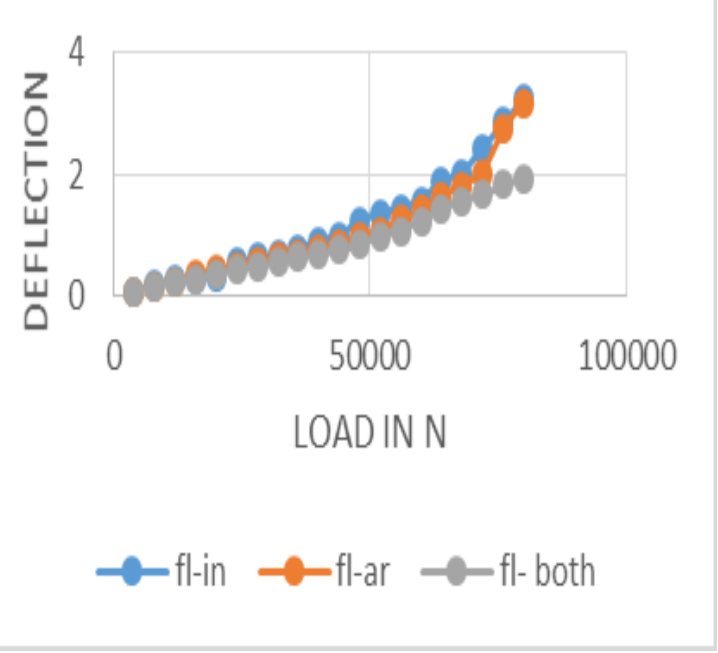

From the figure, it can be seen that the deflection are minimum for a given load in case of beams retrofitted with CFRP inside and around the opening in Flexural zone. 
The load deflection graph for the beams retrofitted with GFRP in Shear zone is shown in Figure 6

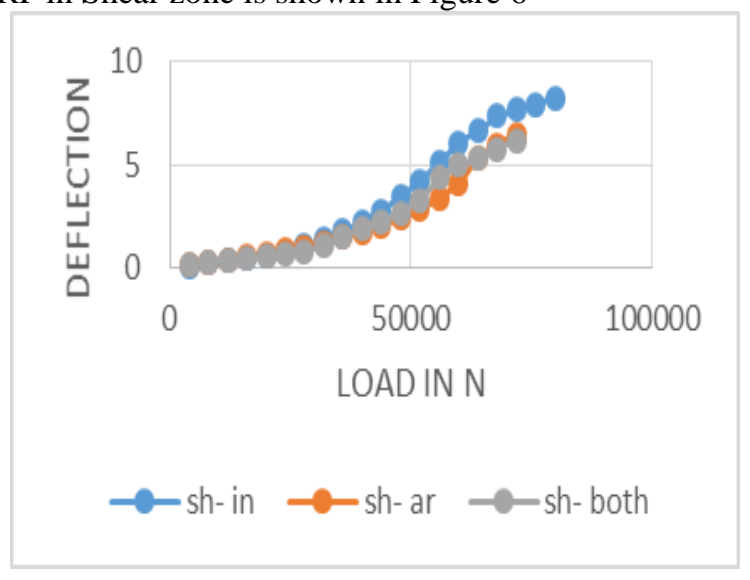

From the figure, it can be seen that the deflection are minimum for a given load in case of beams retrofitted with GFRP inside and around the opening in Shear zone.

The load deflection graph for the beams retrofitted with GFRP in Shear zone is shown in Figure 7

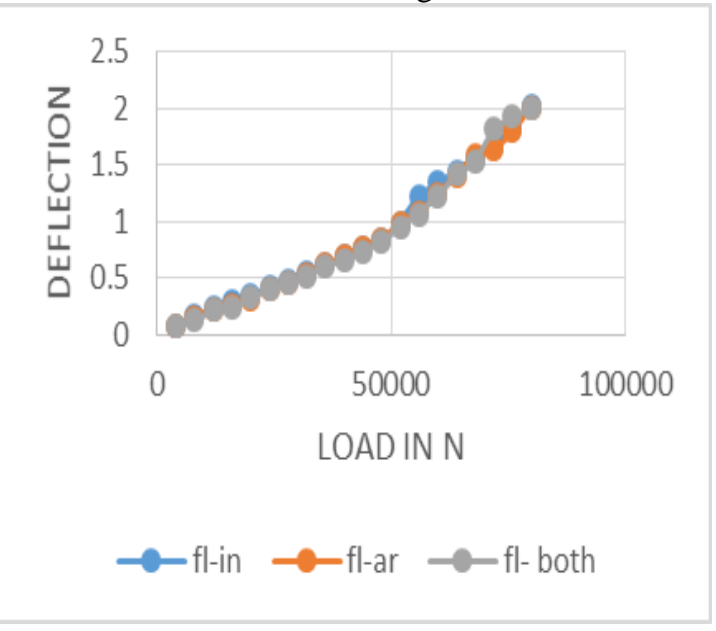

From the figure, it can be seen that the deflection are minimum for a given load in case of beams retrofitted with GFRP inside and around the opening in Flexural zone.

The crack pattern for the beam retrofitted with CFRP in Shear zone for both around and inside the opening is shown in Figure 8

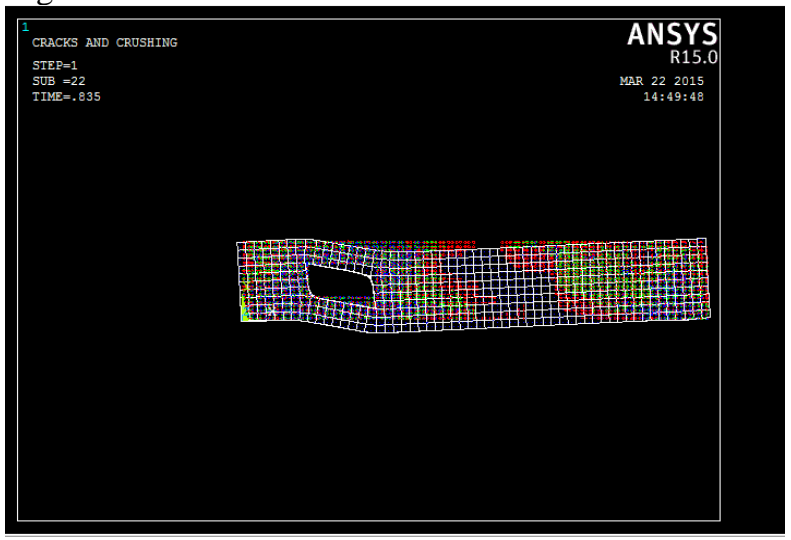

Figure 8. Crack Pattern for CFRP in Shear zone
The crack pattern for the beam retrofitted with CFRP in Flexural zone for both around and inside the opening is shown in Figure 9

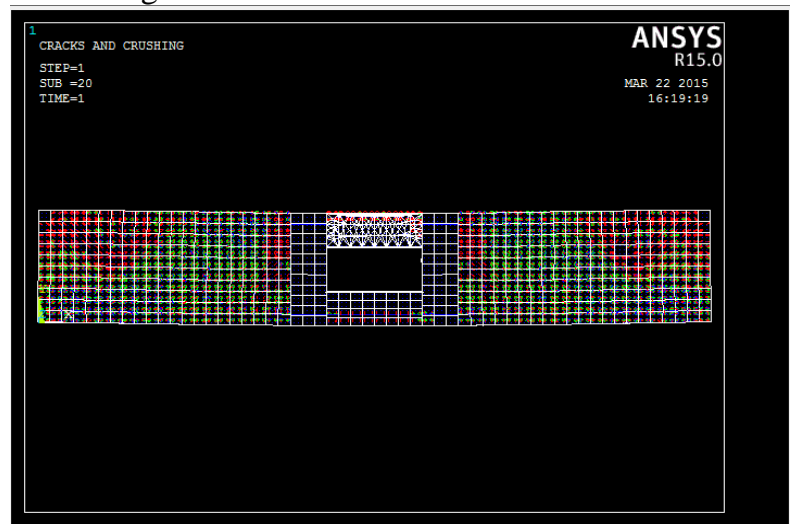

Figure 9. Crack Pattern for CFRP in Flexural zone

\section{CONCLUSION}

- The load carrying of the beam were found to decreases due to rectangular opening compared to solid beam. Due to stress concentration, around the opening edges the diagonal cracks were developed.

- The external strengthening inside and around the opening increases the stiffness of the beam and also increases the load carrying capacity.

- $\quad$ Strengthening of the beam around the opening is more effective than inside the opening for both CFRP and GFRP techniques.

- $\quad$ Strengthening of the beam opening by using CFRP and GFRP sheets for both around and inside the opening increases the load carrying capacity significantly and the percentage of increase in load carrying capacity for CFRP sheets is $50 \%$, where as in GFRP sheets percentage of increase in load carrying capacity is $37 \%$.

- It can be concluded that the strengthening with CFRP around and inside the opening is more effective and is considered as best strengthening scheme from the overall study.

- These techniques help the engineers to strengthen the openings provided in existing building.

\section{REFERENCES}

[1] Santhakumar. R and Chandrasekaran" Analysis of Retrofitted Reinforced Concrete Shear Beams using Carbon Fibre Composites", Electronic Journal of Structural Engineering, 4 (2004), PP. 66-74.

[2] Shaishav R. Viradiya1, Tarak P. Vora "Comparative study of experimental and analytical results of FRP strengthened beams in flexure", IJRET: International Journal of Research in Engineering and Technology eISSN: 2319-1163 | pISSN: 2321-7308, Volume-3, Issue- 4, April -2014, PP. 555-559.

[3] Lavate .R.S, Patil. A. T, Patil A. M, Hargude. N.V, "Dynamic Response Analysis of Fiber Reinforced Composite Beam", IOSR Journal of Mechanical and 
Civil Engineering (IOSR-JMCE) ISSN: 2278-1684, PP: $38-47$.

[4] Omran H.Y, Zangeneh.P and EL-Hacha. R, "Finite element modelling of steel-concrete composite beams strengthened with prestressed CFRP plate" International institute for FRP, December- 2009, PP. 187-192. 